Egyptian Journal of Aquatic Biology \& Fisheries

Zoology Department, Faculty of Science,

Ain Shams University, Cairo, Egypt.

ISSN $1110-6131$

Vol. 25(1): $91-110$ (2021)

www.ejabf.journals.ekb.eg

\title{
Morphometric-Meristic Characters and Length-Weight Relationships of Macrobrachium mammillodactylus (Thallwitz, 1892) Inhabiting Downstream of Rongkong Watershed, South Sulawesi, Indonesia
}

\author{
Jurniati Jurniati $^{1,3 *}$, Diana Arfiati ${ }^{2}$, Asus M. S. Hertika ${ }^{2}$, and Andi Kurniawan ${ }^{2}$ \\ ${ }^{* 1}$ Postgraduate Program, Faculty of Fisheries and Marine Science, Universitas Brawijaya, Malang \\ 65145 East Java, Indonesia \\ ${ }^{2}$ Department of Aquatic Resources Management, Faculty of Fisheries and Marine Science, \\ Universitas Brawijaya, Malang 65145, East Java, Indonesia \\ ${ }^{3}$ Department of Aquaculture, Faculty of Fisheries, Universitas Andi Djemma, Palopo 91911, \\ South Sulawesi, Indonesia \\ "Corresponding Author: unieqzul@gmail.com
}

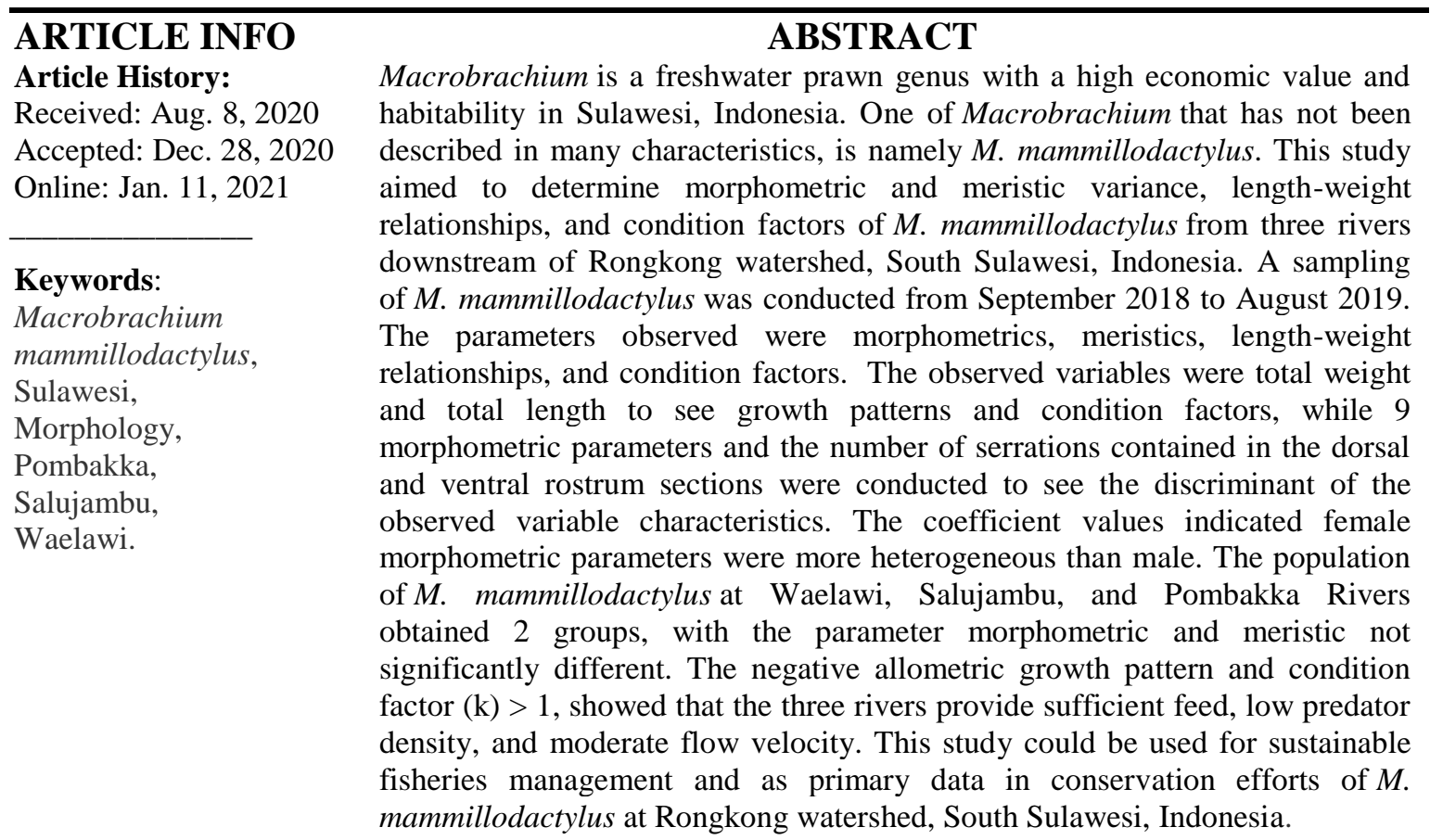

\section{INTRODUCTION}

Indonesia's freshwater organisms are very diverse and have high potential for aquaculture. One of the many of genus of freshwater organisms found in Indonesia is Macrobrachium freshwater prawns. These freshwater prawns were divided into major 
and minor prawn depending upon their body size. Majority of major prawn species are marine and few of them are freshwater (Kumar et al., 2018). Since the end of the $19^{\text {th }}$ century, the genus Macrobrachium has been reported from Ilhabela (Mossolin et al., 2010). The invasion of family Palaemonidae to freshwaters was recorded during the late Mesozoic or early Cenozoic era (Anger, 2013). Macrobrachium is a species of freshwater prawn that widely distributed in Indonesia (Binur and Pancoro, 2017). The genus Macrobrachium is distributed in the world's biogeographic regions, namely the Afrotropical, Australasian, Neotropical, and Oriental regions (de Grave et al., 2008). Macrobrachium belongs to the family Palaemonidae and seemingly easy to differentiated from other genera (Torati $\boldsymbol{e t}$ al., 2011) and have 230 species (Andrade $\boldsymbol{e t}$ al., 2017). The genus Macrobrachium has a hepatic spine, the last three legs have a simple dactylus, and has no supraorbital and branchiostegal spines. It has well developed, compressed and toothed rostrum.The telson has two pairs of dorsal and posterior spines (de Grave et al., 2011). Macrobrachium is a freshwater prawns that has high economic value (Trijoko $\boldsymbol{e t}$ al., 2015; Fadli et al., 2018).

Sulawesi is one of the freshwater prawn habitats of the genus Macrobrachium and has economic value to be developed. Laewa et al. (2018) reported the Sulawesi island is one of the distribution regions of the genus Macrobrachium. Sulawesi Island is included in the transition zone in the Wallace grouping and reported to store biodiversity of high potential biota (Tanod et al., 2019; Menajang et al., 2020). Sulawesi Island has biodiversity with a high level of endemicity and is one of the areas of spreading freshwater prawn (Annawaty et al., 2016; Swiyanto et al., 2018; Dwiyanto et al., 2020).

Previous studies reported that there were 19 species from Sulawesi, Indonesia, namely M. gracilirostre (Wowor et al., 2009); M. bariense, M. mammillodactylus, M. placidum, M. sulcicarpale, M. weberi, M. spinipes (de Grave et al., 2013); M. lepidactyloides (Annawaty and Wowor, 2015); M. rosenbergii; M. idae (Wahidah $\boldsymbol{e t}$ al., 2015, 2017); M. lanchesteri (Mangesa et al., 2016); M. scabriculum (Dwiyanto et al., 2017); Macrobrachium australe, M. horstii, M. lar, M. placidulum (Swiyanto et al., 2018); M. equidens, M. latidactylus (Laewa et al., 2018) and (Rahayu and Annawaty, 2019); and M. esculentum (Jurniati et al., 2020, 2021). One of the species whose characteristics have not been described was M. mammillodactylus.

de Grave et al. (2013) in their report only explained the species of $M$. mammillodactylus originating from Sulawesi, Indonesia. While Jose and Harikrishnan (2018) reported M. mammillodactylus from Philippines living in euryhaline habitats. Recently, there is no publication analyzing the characteristics of M. mammillodactylus from South Sulawesi, Indonesia. Information on the genus Macrobranchium of South Sulawesi comes from M. horstii from a river near Palopo (Wowor and Choy, 2001); $M$. rosenbergii and M. idae from the Waelawi, Kariango, and Kalibone rivers (Wahidah $\boldsymbol{e t}$ al., 2017); and Lake Tempe (Wahidah et al., 2015); M. esculentum from the Pongkeru River (Wowor et al., 2009). This study is the first report to measure morphometric- 
meristic characteristics and the length-weight relationship of M. mammillodactylus from South Sulawesi, Indonesia.

The Rongkong watershed, especially in the downstream, is a main habitat of freshwater prawns that is a source of livelihood for the local community. $M$. mammillodactylus is the most dominant catch of artisanal fishermen who use fishing traps (locally named "kopa"). In the last few years, the catch of fishermen has been declining due to land management (mining, plantations); residues of inorganic fertilizers from agricultural land, anthropogenic waste and destructive fishing (Setiawan and Nandini, 2006). As the rivers are essential reservoirs for Macrobrachium, it is important to study the fitness of rivers population, so that it can be useful in the conservation program of a species (Maidin et al., 2017). Therefore, this study aimed to determine morphometric-meristic variance, length-weight relatioships and condition factor of Macrobrachium mammillodactylus from three rivers in the downstream of Rongkong watershed, South Sulawesi. This study could be used as a preliminary data for conservation management of M. Mammillodactylus in South Sulawesi, Indoensia.

\section{MATERIALS AND METHODS}

\section{Study area}

Sampling was carried out from September 2018 to August 2019 in the downstream of Rongkong watershed. There were 3 rivers in downstream Rongkong watershed: Waelawi; Salujambu; and Pombakka which are the Macrobrachium fishing area. Local fishermen install bamboo fishing traps (local name: kopa) along the banks of the rivers. There were 3 stations at each sampling location (river). The coordinates of the sampling location could see in Table 1 and Fig. 1.

Table 1. Coordinate point Sampling location Macrobrachium mammillodactylus

\begin{tabular}{|c|c|c|c|}
\hline $\begin{array}{l}\text { Sampling } \\
\text { Location }\end{array}$ & Station I & Station 2 & Station 3 \\
\hline Waelawi & $\begin{array}{c}\text { Lat. } 2^{\circ} 51^{\prime} 05.03 ” \mathrm{~S} \\
\text { Long } 120^{\circ} 18^{\prime} 21.54 ” \mathrm{E}\end{array}$ & $\begin{array}{c}\text { Lat } 2^{\circ} 51 ' 11.37 " \mathrm{~S} \\
\text { Long } 120^{\circ} 18^{\prime} 30.41 ” \mathrm{E}\end{array}$ & $\begin{array}{c}\text { Lat } 2^{\circ} 51^{\prime} 19.05^{\prime} \mathrm{S} \\
\text { Long } 120^{\circ} 18^{\prime} 43.62^{\prime \prime} \mathrm{E}\end{array}$ \\
\hline Salujambu & $\begin{array}{c}\text { Lat } 2^{\circ} 49^{\prime} 19.51 " \mathrm{~S} \\
\text { Long } 120^{\circ} 15,18.22^{\prime \prime} \mathrm{E}\end{array}$ & $\begin{array}{c}\text { Lat } 2^{\circ} 49^{\prime} 24.07 " \mathrm{~S} \\
\text { Long } 120^{\circ} 15^{\prime} 38.26^{\prime \prime} \mathrm{E}\end{array}$ & $\begin{array}{c}\text { Lat } 2^{\circ} 50^{\prime} 18.57^{\prime} \mathrm{S} \\
\text { Long } 120^{\circ} 15,21.18^{\prime \prime} \mathrm{E}\end{array}$ \\
\hline Pombakka & $\begin{array}{c}\text { Lat } 2^{\circ} 51 \text { ' } 34.40^{\prime \prime} \mathrm{S} \\
\text { Long } 120^{\circ} 16^{\prime} 14.08^{\prime \prime} \mathrm{E}\end{array}$ & $\begin{array}{c}\text { Lat } 2^{\circ} 52^{\prime} 12.30^{\prime \prime} \mathrm{S} \\
\text { Long } 120^{\circ} 16^{\prime} 29.23 ” \mathrm{E}\end{array}$ & $\begin{array}{c}\text { Lat } 2^{\circ} 52,51.29 ” \mathrm{~S} \\
\text { Long } 120^{\circ} 16^{\prime} 24.08^{\prime \prime} \mathrm{E}\end{array}$ \\
\hline
\end{tabular}

\section{Research Procedures}

Random sampling was conducted 12 times (once a month) using kopa. Samples were put into a coolbox, then transported and deposited into the Basic Laboratory of the Faculty of Fisheries, Andi Djemma University, Palopo, South Sulawesi, Indonesia. Samples were preserved in $70 \%$ alcohol. Sexing of $M$. mammillodactylus was performed based on morphological features (Cuvin-Aralar, 2014). The number of $M$. 
mammillodactylus from the Waelawi river was 1080 individu (440 males, 640 females); Salujambu river was 1080 individu (448 male, 632 female); and Pombakka River was 1065 individu (438 males and 627 females).

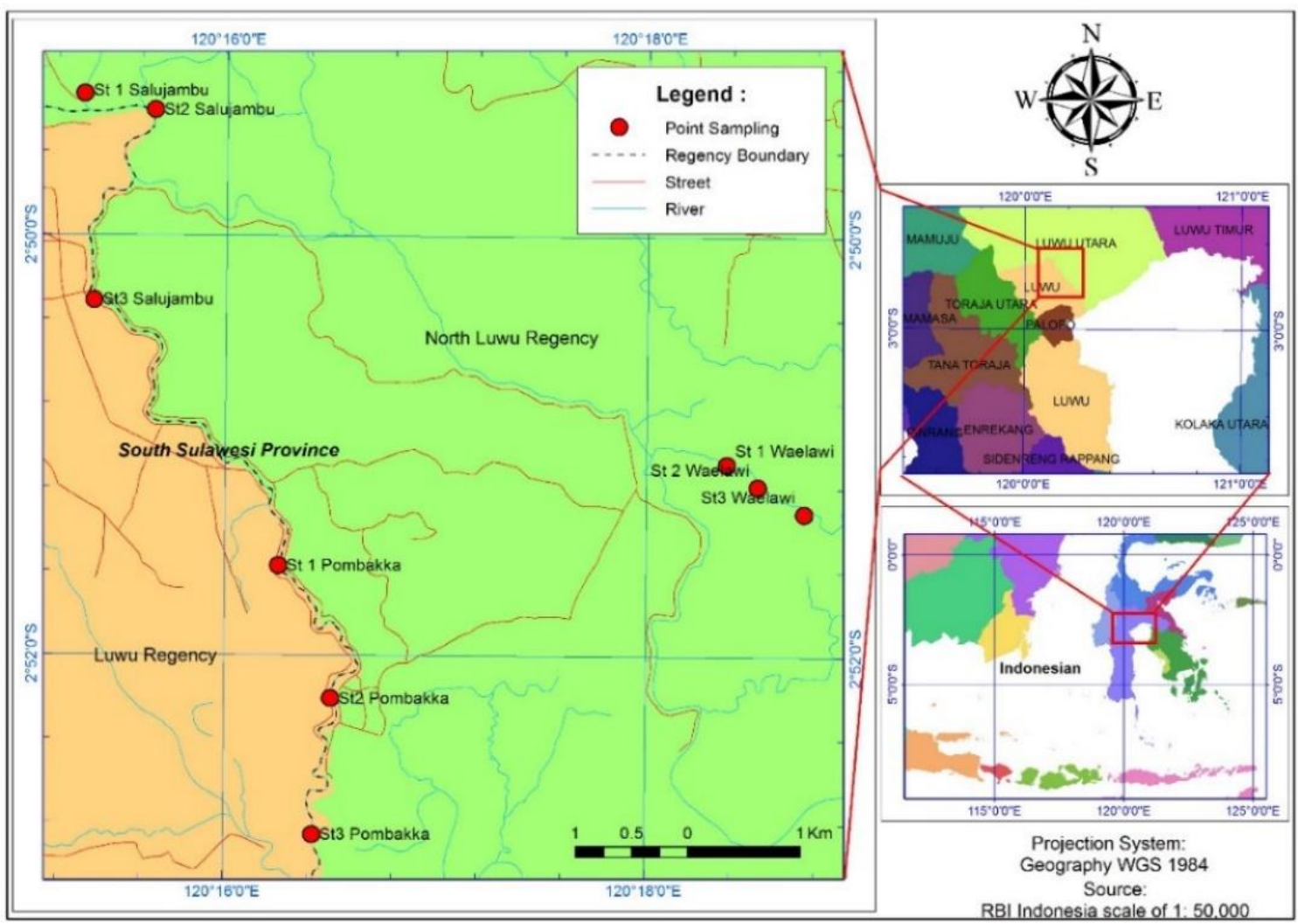

Fig. 1. Map of Sampling area of M. mammillodactylus in Rongkong Watershed, South Sulawesi, Indonesia

Morphometric and meristic measurements (Table 2) were performed following method developed by Short (2004); Munasinghe and Thushari (2010); Adite et al. (2013), by using digital caliper (0.01 $\mathrm{mm}$ accuracy). Measurements of total weight was conducted using a digital scale Acis Ad 300i (accuracy $0.01 \mathrm{~g}$ ). Data on morphometric and meristic measurements from three rivers presented to compare the population. Meristic parameters were measured by counting the number of teeth at the dorsal (upper) and ventral (lower) rostrum.

The allometric linear model (LAM) were used to calculate parameters a and $b$ through measurements of changes in weight and length. Correction of bias of changes in the mean weight of logarithmic units was used to predict the length parameters according to allometric equations of de Robertis and Williams (2008):

$$
W=a L^{b}
$$

Growth patterns was estimated from the value of $b$. If $b=3$, then weight gain is balanced with length gain (isometric). If $b<3$, then the length gain is faster than the weight gain (negative allometrics). If $b>3$, then weight gain is faster than length gain (positive allometrics). 
Table 2. Characteristics, symbol, and definition characteristic morphology M. mammillodactylus

\begin{tabular}{|c|c|c|c|}
\hline No. & Characteristics & Symbol & Defenition of Characteristics \\
\hline A. & Morphometric & & \\
\hline 1 & Total length & TL & Length from antenula to telson end \\
\hline 2 & Abdominal length & $\mathrm{AL}$ & Length from the front carapace to the end of Telson \\
\hline 3 & Telson length & Tel & Maximum length of telson \\
\hline 4 & Carapace length & $\mathrm{CL}$ & $\begin{array}{l}\text { Length from the base of the eye to the front of the } \\
\text { carapace }\end{array}$ \\
\hline 5 & Carapace width & $\mathrm{Cw}$ & Carapace Maximum Width \\
\hline 6 & $\begin{array}{l}\text { Carapace diagonal } \\
\text { length }\end{array}$ & $\mathrm{CdL}$ & The length of the base of the eye to the lower carapace \\
\hline 7 & $\begin{array}{l}\text { Length of the first } \\
\text { abdominal }\end{array}$ & LA1 & Maximum length of the first abdominal segment \\
\hline 8 & $\begin{array}{l}\text { Length of the second } \\
\text { abdominal }\end{array}$ & LA2 & Maximum length of the second abdominal segment \\
\hline 9 & Rostrum length & RL & Length from the tip to the base of Rostrum \\
\hline$B$. & Meristic & & \\
\hline 1 & $\begin{array}{l}\text { Number of upper teeth } \\
\text { of rostrum }\end{array}$ & NUT & Total count of upper teeth of the Rostrum \\
\hline 2 & $\begin{array}{l}\text { Number of lower teeth } \\
\text { of rostrum }\end{array}$ & NLT & Total count of lower teeth of the Rostrum \\
\hline
\end{tabular}

Condition Factors $(\mathrm{K})$ was established to evaluate the condition of each individual. Wr was determined based on the Rypel and Richter (2008) equation as follows:

$$
W r=\left(\frac{W}{W S}\right) \times 100
$$

Wr was the relative weight, $\mathrm{W}$ was the weight of individual prawn, and Ws was the standard weight predicted from the same sample because it calculated from the combined length-weight regression, through distances between species:

$$
W s=a L^{b}
$$

The Fulton condition coefficient $(\mathrm{K})$ was determined based on the (Okgerman, 2005) equation with the following formula:

$$
K=W L^{-3} \times 100
$$

Where $\mathrm{K}$ was a condition factor, $\mathrm{W}$ was the total weight $(\mathrm{g}), \mathrm{L}$ was the total length $(\mathrm{mm})$, and -3 is the coefficient of length to ensure that the $K$ value tends to be 1 .

\section{Data Analysis}

Morphological characteristics were analyzed using principal component analysis (PCA) to obtain morphometric characteristics grouping. Hierarchical cluster analysis to analyze a phenotypic level of similarity in the form of the Dendrogram. Discriminant analysis (DA) to analyze description of the morphometric character of each population of $M$. mammillodactylus using IBM SPSS 21 software. Allometric linear models (ALM) was applied to obtain growth patterns. 


\section{RESULTS}

\section{Identification}

Samples obtained from the downstream of Rongkong watershed were morphologically identified as Macrobrachium mammillodactylus (Thallwitz, 1892). The identification was carried out by Dr. Daisy Wowor (Crustacean Laboratory researcher, Center for Biological Research - Indonesian Institute of Sciences), with letter number B5940/IPH.1/KS.02.03/XI/2018. This is first report about M. mammillodactylus from South Sulawesi, Indonesia. The identification process was based on morphometric and meristic characters, especially rostrum, which is a key taxonomy. The freshwater prawn samples found in the downstream Rongkong watershed were medium to adult size. The sample had a schapocherite length that was shorter than the length of the rostrum, the rostral teeth were equally spaced, 8-14 teeth on the dorsal (NUT) and 3-6 teeth in the ventral rostrum (NLT) (Wowor and Choy, 2001). Sample of M. mammillodactylus samples from downstream of the Rongkong watershed, South Sulawesi, Indonesia, could be seen in Fig. 2.

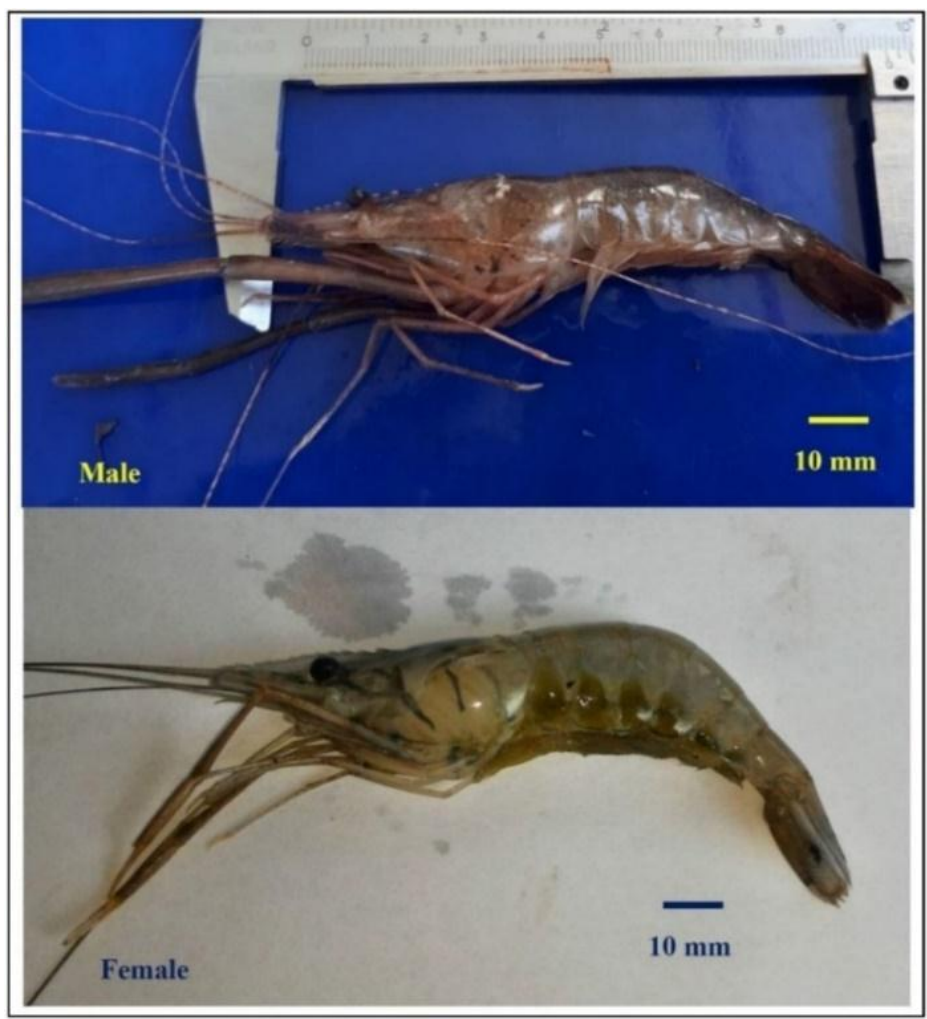

Fig. 2. Macrobrachium mammillodactylus from downstream of the Rongkong watershed, South Sulawesi, Indonesia

\section{Morphometric}

The morphology of a species was influenced by the habitat or environment where the species lives. The morphometric and meristic characters of the male and female populations were also measured separately. In the Waelawi, Salujambu and Pombakka Rivers, male M. mammillodactylus has almost the same carapace length (CL). 
Meanwhile, female M. mammillodactylus, carapace length (CL) in the Waelawi River was greater than in the Pombakka and Salujambu Rivers. Morphometric characteristics of M. mammillodactylus can be seen in Table 3.

Tabel 3. Morphometric characteristics of $M$. mammillodactylus population in Rongkong Watershed, South Sulawesi, Indonesia

\begin{tabular}{|c|c|c|c|c|c|c|c|}
\hline \multirow{2}{*}{$\begin{array}{l}\text { Sampling } \\
\text { Location }\end{array}$} & \multirow{2}{*}{$\begin{array}{l}\text { Charac- } \\
\text { teristics }\end{array}$} & \multicolumn{3}{|c|}{ Female } & \multicolumn{3}{|c|}{ Male } \\
\hline & & Mean \pm SE & Range & CV (\%) & Mean \pm SE & Range & CV (\%) \\
\hline \multirow{9}{*}{ Waelawi } & $\mathrm{TL}$ & $5.87 \pm 0.05$ & $2.11-9.80$ & 19.68 & $6.19 \pm 0.06$ & $2.42-9.91$ & 20.37 \\
\hline & $\mathrm{AL}$ & $3.32 \pm 0.03$ & $0.50-6.01$ & 19.92 & $3.44 \pm 0.04$ & $0.18-7.38$ & 23.32 \\
\hline & Tel & $0.85 \pm 0.01$ & $0.14-1.93$ & 24.69 & $0.92 \pm 0.01$ & $0.21-2.04$ & 24.00 \\
\hline & CL & $1.49 \pm 0.01$ & $0.31-2.99$ & 23.23 & $1.65 \pm 0.02$ & $0.33-3.52$ & 25.25 \\
\hline & $\mathrm{Cw}$ & $0.99 \pm 0.01$ & $0.13-2.03$ & 25.18 & $1.09 \pm 0.01$ & $0.21-2.38$ & 27.50 \\
\hline & $\mathrm{CdL}$ & $1.66 \pm 0.01$ & $1.02-3.07$ & 21.99 & $1.80 \pm 0.02$ & $0.38-3.61$ & 23.39 \\
\hline & LA1 & $0.29 \pm 0.01$ & $0.13-1.30$ & 35.89 & $0.28 \pm 0.01$ & $0.03-0.81$ & 27.11 \\
\hline & LA2 & $0.64 \pm 0.01$ & $0.29-1.59$ & 25.30 & $0.65 \pm 0.01$ & $0.12-1.96$ & 30.54 \\
\hline & RL & $1.63 \pm 0.01$ & $0.46-2.90$ & 19.62 & $1.72 \pm 0.02$ & $0.59-3.43$ & 21.17 \\
\hline \multirow{9}{*}{ Salujambu } & TL & $5.77 \pm 0.05$ & $0.15-9.94$ & 21.05 & $5.75 \pm 0.05$ & $2.02-9.17$ & 19.61 \\
\hline & AL & $3.22 \pm 0.03$ & $1.07-6.17$ & 20.11 & $3.21 \pm 0.03$ & $1.12-5.81$ & 19.39 \\
\hline & Tel & $0.84 \pm 0.01$ & $0.13-1.97$ & 24.92 & $0.86 \pm 0.01$ & $0.15-1.93$ & 19.96 \\
\hline & CL & $1.47 \pm 0.01$ & $0.32-2.83$ & 23.54 & $1.51 \pm 0.02$ & $0.31-2.95$ & 23.46 \\
\hline & $\mathrm{Cw}$ & $0.98 \pm 0.01$ & $0.21-2.48$ & 27.38 & $1.01 \pm 0.01$ & $0.11-1.95$ & 25.53 \\
\hline & $\mathrm{CdL}$ & $1.60 \pm 0.02$ & $0.22-3.24$ & 24.17 & $1.65 \pm 0.02$ & $0.21-2.97$ & 24.62 \\
\hline & LA1 & $0.27 \pm 0.01$ & $0.12-1.86$ & 43.42 & $0.27 \pm 0.01$ & $0.10-1.23$ & 30.57 \\
\hline & LA2 & $0.62 \pm 0.01$ & $0.10-1.72$ & 26.78 & $0.58 \pm 0.01$ & $0.10-1.59$ & 26.54 \\
\hline & RL & $1.59 \pm 0.01$ & $0.41-2.95$ & 19.74 & $1.62 \pm 0.01$ & $0.51-2.78$ & 16.74 \\
\hline \multirow{9}{*}{ Pombakka } & TL & $5.86 \pm 0.05$ & $1.65-9.78$ & 20.80 & $5.97 \pm 0.06$ & $0.71-9.22$ & 21.34 \\
\hline & $\mathrm{AL}$ & $3.25 \pm 0.03$ & $0.64-6.53$ & 21.17 & $3.33 \pm 0.04$ & $1.08-7.38$ & 22.76 \\
\hline & Tel & $0.87 \pm 0.01$ & $0.20-1.97$ & 25.59 & $0.89 \pm 0.01$ & $0.14-2.05$ & 23.77 \\
\hline & CL & $1.49 \pm 0.01$ & $0.32-2.49$ & 22.41 & $1.56 \pm 0.02$ & $0.32-3.52$ & 25.19 \\
\hline & $\mathrm{Cw}$ & $0.99 \pm 0.01$ & $0.22-1.96$ & 25.03 & $1.05 \pm 0.01$ & $0.25-2.35$ & 24.80 \\
\hline & $\mathrm{CdL}$ & $1.63 \pm 0.02$ & $0.23-2.95$ & 24.12 & $1.72 \pm 0.02$ & $0.22-3.24$ & 24.86 \\
\hline & LA1 & $0.31 \pm 0.01$ & $0.11-1.07$ & 39.69 & $0.29 \pm 0.01$ & $0.12-1.23$ & 42.31 \\
\hline & LA2 & $0.63 \pm 0.01$ & $0.10-1.21$ & 25.92 & $0.61 \pm 0.01$ & $0.12-1.51$ & 29.79 \\
\hline & RL & $1.61 \pm 0.01$ & $0.41-2.58$ & 20.35 & $1.69 \pm 0.02$ & $0.41-3.43$ & 20.73 \\
\hline
\end{tabular}

$\mathrm{CV}=$ coefficient of variation, Morphometric parameter unit $=\mathrm{mm}$

Table 3 shows that the range of coefficient of variation (CV) was found for all morphometric variables measured from three rivers between $16.74 \%$ and $42.31 \%$, the lowest variance was the male population's rostrum length parameter. Simultaneously, the highest was the first abdominal length parameter in female population from Salujambu. Morphometric variability in the population, high for female groups $(19.62 \%-43.42 \%)$, than males (16.74-42.31\%).

Correlation analysis was performed to determine the parameters that affect the carapace length size of the sample. Correlation between variables of carapace length (Y) with parameters of total length, abdominal length, telson length, carapace width, carapace diagonal length, length of first abdominal, length of second abdominal, and rostrum length as an influencing variable $(\mathrm{X})$ with linear regression analysis can be seen in Table 4. 
Table 4. Correlation between carapace length with eight morphometric parameters of M. mammillodactylus in Rongkong Watershed, South Sulawesi, Indonesia

\begin{tabular}{ccccccc}
\hline \multirow{2}{*}{ Parameters } & \multicolumn{2}{c}{ Waelawi } & \multicolumn{2}{c}{ Salujambu } & \multicolumn{2}{c}{ Pombakka } \\
\cline { 2 - 7 } & Male & Female & Male & Female & Male & Female \\
\hline a & -0.159 & 0.000 & -0.076 & 0.036 & -0.123 & 0.047 \\
b1 & 0.028 & 0.032 & 0.088 & 0.064 & 0.067 & 0.068 \\
b2 & 0.010 & 0.023 & 0.030 & -0.015 & 0.006 & -0.005 \\
b3 & 0.157 & 0.071 & 0.176 & 0.050 & 0.020 & 0.048 \\
b4 & 0.239 & 0.087 & 0.200 & 0.284 & 0.482 & 0.076 \\
b5 & 0.504 & 0.609 & 0.361 & 0.410 & 0.305 & 0.407 \\
b6 & 0.840 & 0.008 & 0.177 & 0.145 & 0.130 & 0.236 \\
b7 & -0.072 & -0.035 & -0.024 & -0.137 & -0.075 & 0.079 \\
b8 & 0.054 & 0.056 & -0.001 & 0.114 & 0.054 & 0.056 \\
r & 0.817 & 0.770 & 0.768 & 0.758 & 0.783 & 0.787 \\
n & 440 & 640 & 448 & 632 & 438 & 627 \\
\hline CL = (a + b1*TL $)+(\mathrm{b} 2 * \mathrm{AL})+(\mathrm{b} 3 * \mathrm{Tel})+(\mathrm{b} 4+\mathrm{Cw})+(\mathrm{b} 5 * \mathrm{CdL})+(\mathrm{b} 6 * \mathrm{LA} 1)+\mathrm{b} 7 * \mathrm{LA} 2)+(\mathrm{b} 8 * \mathrm{RL})$ \\
\hline \multicolumn{7}{c}{}
\end{tabular}

Table 4 shows the range of correlation coefficient values (r) (0.87-0.90). Positive correlation coefficient values indicate that changes in TL, AL, Tel, Cw, CdL, LA1, and LA2 morphometric parameters will affect the carapace length $(\mathrm{CL})$. The regression equation coefficient showed a significant influence between $C L$ with eight morphometric parameters of M. mammillodactylus (male and female) in Waelawi, Salujambu, and Pombakka rivers. Population diversity based on morphological differences may indicate the presence of genetic diversity among the population. However, further study was needed in assessing genetic characteristics.

The cluster analysis in Fig. $\mathbf{3}$ shows two population groups (male and female) with similarities based on the observed characters. The first group obtained FS (female population of Salujambu river), FW (female population of Waelawi river), FP (female population of Pombakka river), and MS (male population of Salujambu river). The second group was a population of MP (male population of Pombakka river) and MW (male population of Waelawi river).

Discriminant analysis (DA) showed the separation of the population in the Waelawi, Salujambu, and Pombakka river produced very close centroid graphs (Fig. 4). The analysis showed that the eigenvalue of the first was only $12 \%$, and the second function was $1 \%$, with a variation value of $62 \%$ for the first function and $38 \%$ for the second function. These results showed a low value; thus it was not significant in the separation of populations between the three rivers.

Fig. 4 shows the morphometric parameters of M. mammillodactylus population could use as a parameter of separation between rivers. Correlation values of all morphometric parameters was found that the morphometrics of LA2, CdL, AL, TL, CL, $\mathrm{RL}, \mathrm{Tel}$, and $\mathrm{Cw}$ have a correlation with the discriminant function 1, while the LA1 correlates with the discriminant function 2. 


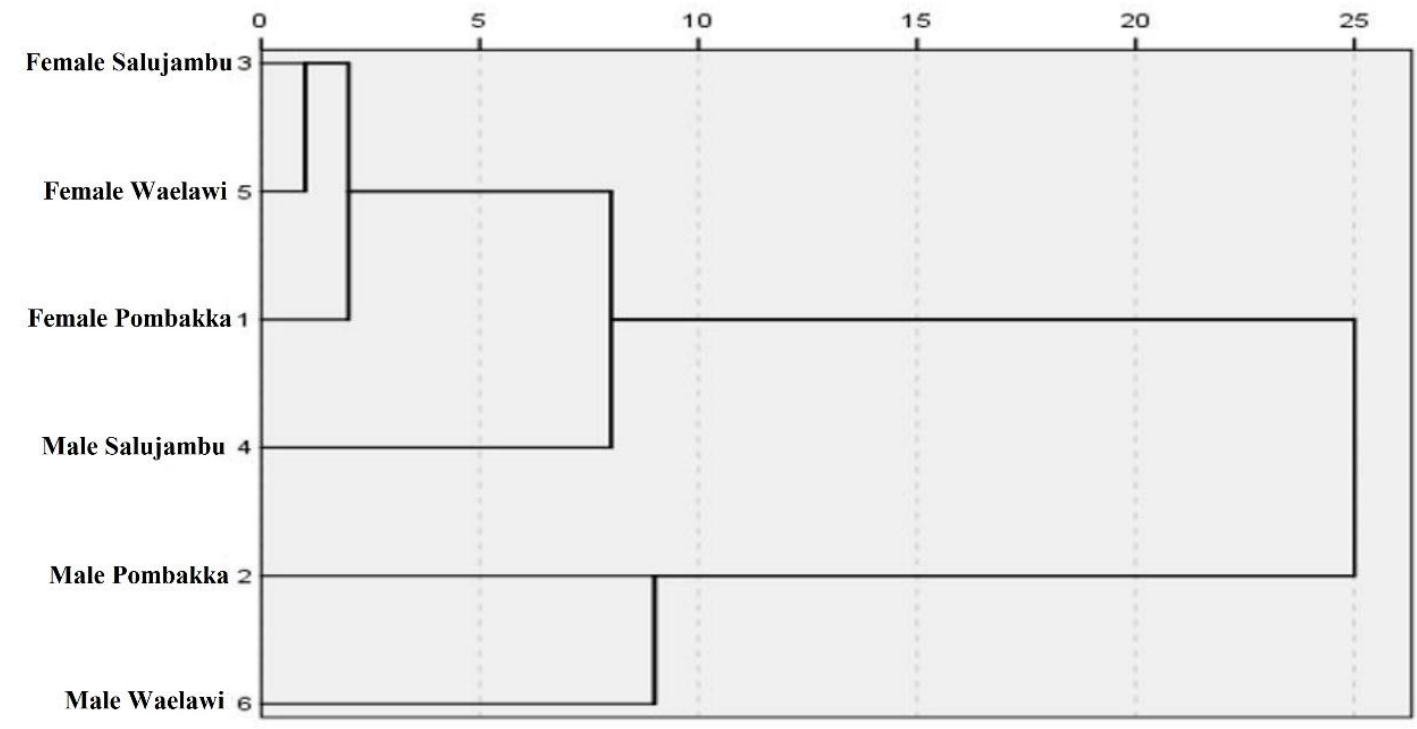

Fig. 3. Dendrogram of characters morphometric M. mammillodactylus in Rongkong Watershed, South Sulawesi, Indonesia

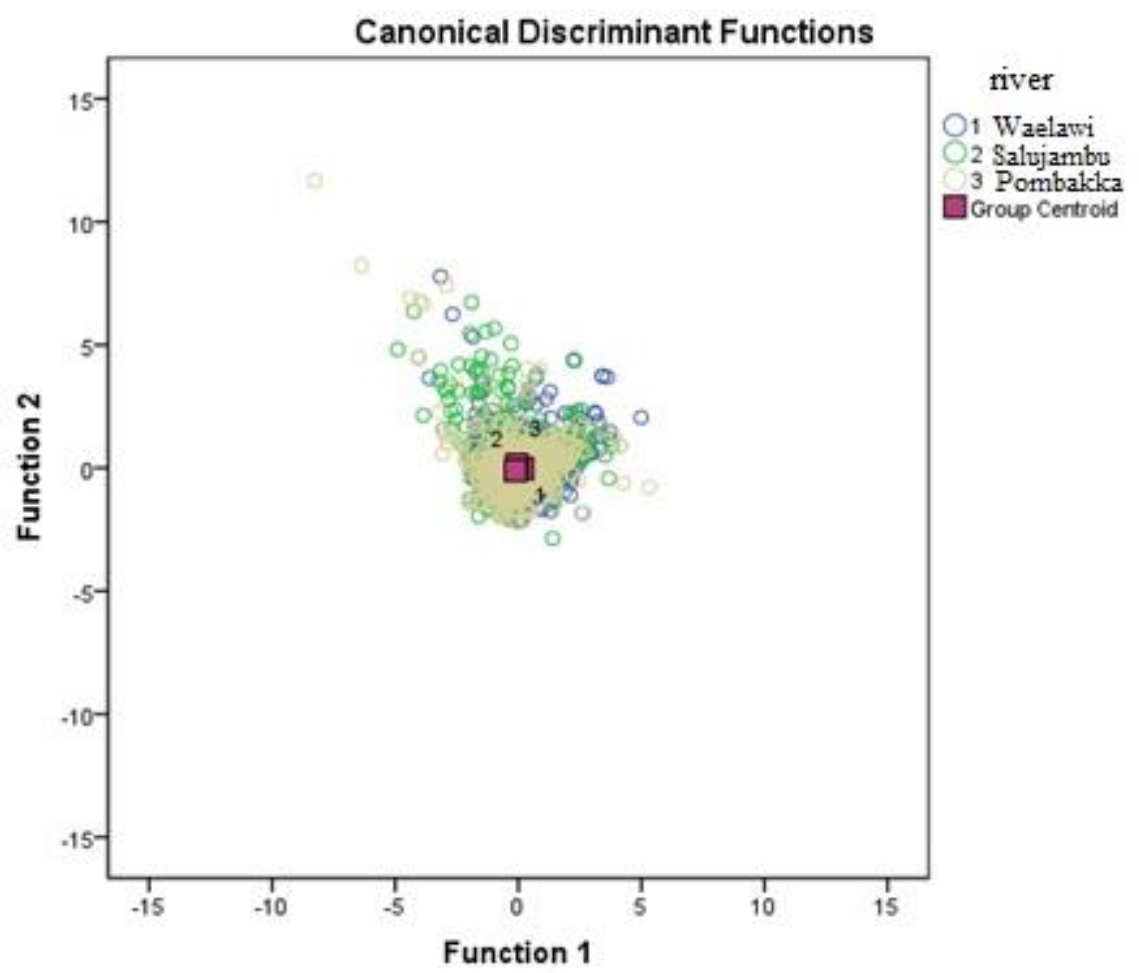

Fig. 4. Cluster Plots between discriminant functions 1 and 2 of M. mammillodactylus

\section{Meristic}

Rostrum spines was commonly used to asses the meristic characteristics of Macrobrachium species. The one-way ANOVA analysis in Table 5 shows no variability of meristic character existed among the population of Macrobrachium mammillidactylus in the three rivers. Measurement of meristic characteristics of M. mammillodactylus from three rivers could be seen in Table 5 . 
Table 5. Meristic characters of M. mammillodactylus in Rongkong Watershed, South Sulawesi,

\begin{tabular}{|c|c|c|c|c|c|}
\hline $\begin{array}{c}\text { Sampling } \\
\text { Location }\end{array}$ & $\begin{array}{c}\text { Meristic } \\
\text { characters }\end{array}$ & $\begin{array}{c}\begin{array}{c}\text { Numbers of } \\
\text { serrations }\end{array} \\
\end{array}$ & Male & Female & Anova \\
\hline Waelawi & $\mathrm{n}$ & & 440 & 640 & \\
\hline Salujambu & $\mathrm{n}$ & & 448 & 632 & \\
\hline Pombakka & $\mathrm{n}$ & & 438 & 627 & \\
\hline \multicolumn{6}{|c|}{ Range number of serrations } \\
\hline Waelawi & \multirow{3}{*}{\multicolumn{2}{|c|}{ NUT }} & $8-14$ & $8-14$ & \\
\hline Salujambu & & & $8-14$ & $8-14$ & \\
\hline Pombakka & & & $8-14$ & $8-14$ & \\
\hline Waelawi & \multirow{3}{*}{\multicolumn{2}{|c|}{ NLT }} & $3-6$ & $3-6$ & \\
\hline Salujambu & & & $3-6$ & $3-6$ & \\
\hline Pombakka & & & $3-6$ & $3-6$ & \\
\hline \multicolumn{6}{|c|}{ Percentage of frequency distribution } \\
\hline \multirow{7}{*}{ Waelawi } & \multirow{21}{*}{ NUT } & 8 & 6,82 & 7,03 & \\
\hline & & 9 & 30,68 & 31,72 & \\
\hline & & 10 & 20,91 & 21,56 & \\
\hline & & 11 & 19,55 & 17,97 & \\
\hline & & 12 & 14,32 & 16,56 & \\
\hline & & 13 & 6,14 & 4,22 & \\
\hline & & 14 & 1,59 & 0,94 & \\
\hline \multirow{7}{*}{ Salujambu } & & 8 & 6,5 & 7,9 & \\
\hline & & 9 & 29.0 & 29,4 & \\
\hline & & 10 & 22,33 & 22,3 & \\
\hline & & 11 & 20,5 & 20,9 & $\mathrm{P}>0.05$ \\
\hline & & 12 & 13,6 & 14,9 & \\
\hline & & 13 & 4,9 & 3,8 & \\
\hline & & 14 & 3,1 & 0,8 & \\
\hline \multirow{7}{*}{ Pombakka } & & 8 & 5,5 & 8,5 & \\
\hline & & 9 & 29,7 & 29,4 & \\
\hline & & 10 & 20,4 & 21,9 & \\
\hline & & 11 & 21,1 & 17,7 & \\
\hline & & 12 & 17,2 & 16,6 & \\
\hline & & 13 & 4,6 & 5,3 & \\
\hline & & 14 & 1,6 & 0,6 & \\
\hline \multirow{4}{*}{ Waelawi } & \multirow{12}{*}{ NLT } & 3 & 62,5 & 69,69 & \multirow{12}{*}{$\mathrm{P}>0.05$} \\
\hline & & 4 & 21,59 & 18,78 & \\
\hline & & 5 & 15,23 & 10,9 & \\
\hline & & 6 & 0,68 & 0,6 & \\
\hline & & 3 & 62,5 & 70,1 & \\
\hline & & 4 & 22,5 & 21,7 & \\
\hline Salujambu & & 5 & 13,4 & 7,0 & \\
\hline & & 6 & 1,6 & 1,3 & \\
\hline \multirow{4}{*}{ Pombakka } & & 3 & 66,6 & 65,2 & \\
\hline & & 4 & 21,5 & 22,8 & \\
\hline & & 5 & 11,0 & 10,7 & \\
\hline & & 6 & 0,9 & 1,3 & \\
\hline
\end{tabular}

\section{Lenght-weight relationships}


The Length-weight relationships was very important in fisheries management. Estimation of the length-weight relationships of $M$. mammillodactylus could be seen in Table 6.

Table 6. Length-weight relationships of M.mammillodactylus from Rongkong Watershed, South Sulawesi, Indonesia

\begin{tabular}{|c|c|c|c|c|c|c|c|c|c|c|}
\hline $\begin{array}{l}\text { Sampling } \\
\text { Location }\end{array}$ & Sex & $n$ & $\begin{array}{l}\text { Range of Total } \\
\text { Length } \\
(\mathrm{mm}) \\
\text { Mean } \pm \text { SD }\end{array}$ & $\begin{array}{l}\text { Range of } \\
\text { Observations } \\
\text { Weight } \\
\text { (g) } \\
\text { Mean } \pm \text { SD }\end{array}$ & $\begin{array}{c}\text { Range of } \\
\text { Prediction } \\
\text { Weight (Ws) } \\
(\mathrm{g}) \\
\text { Mean } \pm \text { SD }\end{array}$ & $\begin{array}{c}\text { Range of } \\
\text { Relative } \\
\text { Weight }(\mathrm{Wr}) \\
(\mathrm{g}) \\
\text { Mean } \pm \mathrm{SD}\end{array}$ & $\begin{array}{c}\text { Range of } \\
\text { Condition } \\
\text { Factor } \\
\text { Fulton K } \\
\text { Mean } \pm \text { SD }\end{array}$ & $\begin{array}{c}\text { Determi- } \\
\text { nation } \\
\text { Coeffi- } \\
\text { cicnt } \\
\left(\mathrm{r}^{2}\right)\end{array}$ & $\begin{array}{l}\text { Corre- } \\
\text { lation } \\
\text { coeffi- } \\
\text { cient }(r)\end{array}$ & $\begin{array}{l}\text { Regre- } \\
\text { ssion (b) }\end{array}$ \\
\hline \multirow{2}{*}{ Waelawi } & Male & 433 & $\begin{array}{c}36.70-134.50 \\
62.70 \pm 13.44\end{array}$ & $\begin{array}{l}1.04-18.02 \\
3.91 \pm 2.68\end{array}$ & $\begin{array}{c}0.87-24.75 \\
3.78 \pm 2.40\end{array}$ & $\begin{array}{l}52.44-171.27 \\
101.26 \pm 19.57\end{array}$ & $\begin{array}{l}0.07-2.80 \\
1.62 \pm 0.57\end{array}$ & 0.880 & 0.938 & 2.582 \\
\hline & Female & 640 & $\begin{array}{c}28.20-103.50 \\
57.58 \pm 11.68\end{array}$ & $\begin{array}{c}1.04-17.25 \\
3.21 \pm 2.20\end{array}$ & $\begin{array}{c}0.47-11.76 \\
3.08 \pm 1.68\end{array}$ & $\begin{array}{c}16.69-178.02 \\
99.76 \pm 21.39\end{array}$ & $\begin{array}{l}0.07-2.85 \\
1.43 \pm 0.56\end{array}$ & 0.803 & 0.896 & 2.470 \\
\hline \multirow{2}{*}{ Salujambu } & Male & 461 & $\begin{array}{l}20.20-96.10 \\
55.76 \pm 11.21\end{array}$ & $\begin{array}{c}1.01-15.60 \\
2.88 \pm 1.68\end{array}$ & $\begin{array}{l}0.36-7.30 \\
2.73 \pm 1.05\end{array}$ & $\begin{array}{c}5.71-236.55 \\
101.30 \pm 28.29\end{array}$ & $\begin{array}{l}0.02-6.81 \\
1.36 \pm 0.65\end{array}$ & 0.601 & 0.775 & 1.904 \\
\hline & Female & 644 & $\begin{array}{c}29.10-101.30 \\
56.99 \pm 12.21\end{array}$ & $\begin{array}{c}0.70-15.25 \\
3.00 \pm 1.88\end{array}$ & $\begin{array}{l}1.09-5.81 \\
2.73 \pm 0.79\end{array}$ & $\begin{array}{l}22.25-358.08 \\
104.23 \pm 32.96\end{array}$ & $\begin{array}{l}0.56-4.10 \\
1.37 \pm 0.60\end{array}$ & 0.735 & 0.857 & 2.124 \\
\hline \multirow{2}{*}{ Pombakka } & Male & 461 & $\begin{array}{c}32.10-134.50 \\
59.72 \pm 13.46\end{array}$ & $\begin{array}{c}0.70-20.47 \\
3.51 \pm 2.70\end{array}$ & $\begin{array}{l}1.36-8.65 \\
3.08 \pm 0.91\end{array}$ & $\begin{array}{l}26.02-381.31 \\
108.05 \pm 41.78\end{array}$ & $\begin{array}{c}0.56-3.26 \\
1.45 \pm 0.65\end{array}$ & 0.810 & 0.900 & 2.570 \\
\hline & Female & 628 & $\begin{array}{l}26.90-98.40 \\
57.63 \pm 12.16\end{array}$ & $\begin{array}{c}0.59-12.73 \\
3.12 \pm 2.03\end{array}$ & $\begin{array}{l}0.66-7.58 \\
2.90 \pm 1.18\end{array}$ & $\begin{array}{l}24.63-244.66 \\
102.57 \pm 26.12\end{array}$ & $\begin{array}{l}1.13-2.75 \\
1.39 \pm 0.62\end{array}$ & 0.788 & 0.888 & 2.315 \\
\hline
\end{tabular}

Table 6 shows correlation coefficient (r) of M. mammillodactylus from three rivers indicates a close relationship between total length and body weight of male and female M. mammillodactylus, where each increase in total length will be followed by weight gain. The correlation coefficient (r) ranges from 0.775 to 0.938 in the three rivers. These high correlation coefficient values indicated a close relationship between total length and body weight of male and female $M$. mammillodactylus. An increase in total length will be followed by an increase in weight gain.. In addition, the coefficient value terminated $\left(\mathrm{r}^{2}\right)$ ranged from 0.601 to 0.880 . This explained that the total weight gain variance between 60 to $88 \%$.

The growth coefficient of M. Mammillodactylus in Table 6 shows the growth pattern of negative allometric $(b<3)$, for the population of Waelawi, Salujambu and Pombakka rivers. In the range of $b$ values in female prawn ranging from $2.124-2.470$, and in male prawn ranging from $1.904-2.582$.

Tabel 6 also shows that observations weight value ranging from $2.88-3.91$, was higher than the prediction weight value of $2.73-3.78$. This indicated that the water qualities in the three rivers were optimal for growth of $M$. mammillodactylus. This was in accordance with the Fulton Condition Factor Values. Male prawn in the three rivers had Fulton condition factors $(\mathrm{K})$ ranging from 1.36 to 1.62 , and relative weight (Wr) ranging from 101.26 to $108.05 \mathrm{~g}$. Whereas in female prawn, the Fulton condition factors $(\mathrm{K})$ ranged from 1.37 to 1.43 , and the relative weight (Wr) ranged from 99.76 to $104.23 \mathrm{~g}$. 


\section{DISCUSSION}

Morphological variation due to characters differences resulted from an adaptation of a species to the environment (Wahidah et al., 2015). This morphological variation can be assessed by morphometric measurements, which are geometric and biological empirical functions (Wahidah et al., 2017). Konan et al. (2010) stated that the interaction between genotypes and the environment resulted in a morphometric characteristic that can be used to identify the phenotype of a population. The same genotype was subjected to different environments, it could produce a wide range of phenotypes. Phenotypic variations are attributable to the effect of the environment on the expression and function of genes influencing the trait (Baye et al., 2011).

Results findings show that the female population's morphometric characters are more heterogeneous than the male population. The ranges of higher CV showed a more heterogeneous morphological character (Ferrito et al., 2007). The highest morphometric $\mathrm{CV}$ of the three rivers populations was the Pombakka river $>$ Waelawi river $>$ Salujambu river. This is presumably because Pombakka River is closer to the Rongkong watershed's mouth, so the prawn in this river is likely more ready to spawn (also indicated by the increase in egg diameter and level of gonad maturity), affecting the length of the carapace. This reflects the life cycle of prawns (especially the genus Macrobrachium) who migrate to the sea as they reach the adult stage to spawn (Bauer, 2013).

Generally, M. mammillodactylus obtained during the study has a relatively large size. Hindell et al. (2008) reported that a species would have a larger size when it migrates for spawning. Kounthongbang et al. (2015) also reported M. yui from northern Laos with carapace length (CL) of about 21-39 cm, has a high gonad somatic index. Ginting et al. (2018) revealed that the total length of $M$. mammillodactylus in the Sibam River, Pekanbaru, Riau, Indonesia, had a total length of 22.6 to $58.7 \mathrm{~mm}$ in male prawns and 25.6 to $32.5 \mathrm{~mm}$ in female prawns. Holthuis (1950) found that M. mammillodactylus could reach a maximum total length of $137 \mathrm{~mm}$. Differences in morphological characteristics, including total length, indicated that there were genotypes that were specifically expressed better in one particular environment but not in other environments (Mariappan and Balasundaram, 2004; Adite et al., 2013; Cartaxana, 2015).

Morphological diversity in an environment showed phenotypic flexibility, which was the ability of an individual to produce more than one alternative form of morphology or behavior as a response to the environmental changes to survive and reproduce (Jayachandran and Indira, 2010; Chen et al., 2015; Mar et al., 2018).

Population characteristics from the three rivers on the 9 morphometric parameters had very close characteristics(Similar). This indicated that the water quality of the three rivers were homogen and then support survival and growth of the prawn in the same way. Observation on morphometric and meristic characters was needed to evaluate genetic diversity. In addition, meristic characters contribute to implementation of management 
plans, including habitat protection, species conservation and culture of Macrobrachium species (Fagnon et al., 2013; Hurtado et al., 2013).

Meristic characters of the prawn did not vary between population. Lawson (2010) said that if two or more populations had the same meristic features, then they were taxonomically inseparable. Ginting et al. (2018) reported that the rostrum of $M$. mammillodactylus in Sibam river, Pekanbaru, Riau, Indonesia, had 7 dorsal teeth and 4 ventral teeth. Whereas Chace and Bruce (1993) reported that the range of the number of rostrum teeth in the dorsal section 7-15 and ventral section 2-5. Macrobrachium mammillodactylus species inhabiting Lake Pangkal Tanjung Balam, Riau, Indonesia, had several teeth 7-9 in the dorsal rostrum and 3-5 in the ventral rostrum (Nurmanita et al., 2019).

Length-weight relationship was performed to examine the growth pattern of $M$. mammillodactylus. The growth patterns of a species could be applied to estimate the production and biomass of the species (Smith ands Addison, 2003; Chang et al., 2012; Neumann et al., 2012). Length-weight relationship was very important in fisheries management as a comparative study for growth to estimate the production and biomass of the species and it can be used as a basis in the assessment of the species populations (Moutopoulos and Stergiou, 2002). Length-weight relationships leads to establish mathematical model between two variables, thus allowing the conversion of one variable to another (Le Cren, 1951; Llopis-Belenguer et al., 2018). In addition, the length-weight relationship had several functions including 1). describing growth in nature (Abohweyere and Williams, 2008; Deekae and Abowei, 2010); 2). determining possible differences between different populations of the same species (Gerritsen and Mcgrath, 2007; King, 2007; Jisr et al., 2018), and 3). describing stock and comparative growth studies (Peixoto et al., 2004; Silva et al., 2015; Maurya et al., 2018; Oliveira et al., 2020).

M. mammillodactylus from three rivers in this study having negative allometric. Previous studies have also reported negative allometric growth patterns in $M$. malcolmsonii (Hossain et al., 2012); M. vollenhovenii (Konan et al., 2014); $M$. nipponense (Tizkar et al., 2018); and Macrobrachium sp. (Ahmadi, 2018). Regression value (b) was an interpretation of body shape that is directly related to weight, which was influenced by ecological factors such as temperature, food supply, season, spawning time, sex, age, and the presence of fishing activities (Ricker, 1973; Hamid et al., 2015; Ogunola et al., 2018).

Condition factors can be used to assess the health status, productivity, and physiological conditions of a populations (Blackwell et al., 2000; Richter, 2007; Muchlisin et al., 2010). Condition factors also reflect the body's morphological characteristics, lipid content, and growth rate (Bister et al., 2000; Froese, 2006; Stevenson and Woods, 2006; Rypel and Richter, 2008; Ighwela et al., 2011). Condition factors describe physical and biological conditions that may change due to 
food availability, parasitic infections, and physiological factors (Le Cren, 1951; Datta $\boldsymbol{e t}$ al., 2013; Ndiaye et al., 2015).

In this study, we found that average weight was higher than the prediction weight. This was in accordance with the Fulton Condition Factor Values. The average of the relative weight (Wr) was above 100 and the fulton condition factor was greater than 1 , indicating that the waters of the three rivers provided sufficient food and low density of predators. This condition was supported by rainfall that occured every month (including in the transitional season) as well as moderate flow velocity in the M. mammillodactylus habitat. Variations in feed supply that occur between seasons can change condition factor seasonally (Offem et al., 2007; Ahmed et al., 2012, 2015). According to Anderson and Newmann (1996); Agista et al. (2019), the value of relative weight (Wr) below 100 for an individual or population indicated problems such as low availability of prey or high density of a predator. Meanwhile, if the relative weight value (Wr) was above 100, it showed the excess availability of a prey or the low density of a predator. In addition, other factors such as biotic, abiotic and fisheries management could also lead to a variety of condition factors (Murphy et al., 1991; Blackwell et al., 2000; Kazemi et al., 2013).

Generally, the condition factors (environmental condition) of M. mammillodactylus in the three rivers were not different. However, the male and female $M$. mammillodactylus condition factors in the Waelawi river are higher than those of Salujambu and Pombakka rivers. Prawn with higher condition factors were expected to have higher fecundity than prawn with lower condition factors (Blackwell et al., 2000; Ara et al., 2014). This study provides information on morphology characteristics and length-weight relationships of $M$. mammillodactylus in the downstream of Rongkong watershed, South Sulawesi, Indonesia.

\section{CONCLUSION}

Analysis of morphometric and meristic characters $M$. mammillodactylus from Waelawi, Salujambu, and Pombakka rivers concluded a close relationship on morphometric and meristic characteristics of M. mammilodactylus populations from the three rivers. The length-weight relationships of $M$. mammillodactylus populations was negative allometric. The observed weight value was higher than the predicted weight; the average condition factor ( $\mathrm{Wr}>100$ and $\mathrm{K}>1$ ) suggested sufficient availability of food and a low number of predators. This study could be used for sustainable fisheries management and as primary data in conservation efforts $M$. mammillodactylus at Rongkong watershed, South Sulawesi, Indonesia.

\section{ACKNOWLEDGMENTS}

We thanks to the Dean of Fisheries and Marine Sciences Faculty Brawijaya University, Dean of Fisheries Faculty Andi Djemma University, and Rector of Andi 
Djemma University who has facilitated, so that this research can be done. The authors also thank to Dr. Daisy Wowor and Adi Wijaya, S.Pd., M.Si., for their assistance in identification and analyzing data. We want to acknowledge the Indonesian Endowment Fund for Education (LPDP-BUDI DN), the Ministry of Finance, and the Ministry of Education and Culture, Republic of Indonesia, which provides scholarships to the first author with a grant No. PRJ-354/LPDP.4/2019.

\section{REFERENCES}

Abohweyere, P. O. and Williams, A. B. (2008). Length-weight relationship and condition factor of Macrobrachium macrobrachion in the Lagos-Lekki lagoon system, Nigeria. Res. J. Biol. Sci., 3: 1333-1336.

Adite, A.; Abou, Y. ; Sossoukpe, E. ; Gbaguidi, H.M.A.G. and Fiogbe, E.D. (2013). Meristic and morphological characterization of the freshwater prawn, Macrobrachium macrobrachion (Herklots, 1851) from the Mono River-Coastal lagoon system, Southern Benin (West Africa): implications for species conservation. Int. J. Biodivers. Conserv., 5(11): 704-714.

Agista, L.; Muhammadar, A.A. and Chaliluddin, M.A. (2019). The relationship of lengthweight and condition factors of layang fish (Decapterus russelli) landed at KUD Gabion of oceanic fishing port, North Sumatra. IOP Conf. Ser. Earth Environ. Sci., 348: 012084.

Ahmadi, A. (2018). Morphometric characteristic of Macrobrachium sp. from Barito river, Indonesia. Int. J. Innov. Stud. Aquat. Biol. Fish., 4(2): 19-31.

Ahmed, Q.; Ali, Q.M. and Bilgin, S. (2015). Seasonal changes in condition factor and weightlength relationship of Tiger Perch, Terapon jarbua (Forsskål, 1775) (Family-Terapontidae) collected from Korangi fish habour, Karachi, Pakistan. Pak. J. Mar. Sci., 24(1-2): 19-28.

Ahmed, Q.; Yousuf, F. ; Siddidui, S. and Türkmen, M. (2012). Seasonal variations in length, weight and condition factor in Katsuwonus pelamis from the coast of Karachi, Pakistan. Karadeniz Fen Bilim. Derg., 2(7): 82-89.

Anderson, R. O. and Newmann, R. M. (1996). Length weight and associated structural indices. In: "Fisheries Techniques." Murphy, B.R. \& Wilis, D.W. (Eds.). American Fisheries Society, Maryland, pp. 447-481.

Andrade, K. S. P.; Araújo, M.S.L.C. and Nunes, J.L.S. (2017). New records of Macrobrachium spence Bate, 1868 (Decapoda, Palaemonidae) from the northern coast of Brazil. Check List, 13(4): 379-390.

Anger, K. (2013). Neotropical Macrobrachium (Caridea: Palaemonidae): on the biology, origin, and radiation of freshwater-invading shrimp. J. Crust. Biol., 33(2): 151-183.

Annawaty, A.; Wowor, D. ; Farajallah, A. ; Setiadi, D. and Suryobroto, B. (2016). Habitat preferences and distribution of the freshwater shrimps of the genus Caridina (Crustacea: Decapoda: Atyidae) in lake Lindu, Sulawesi, Indonesia. HAYATI J. Biosciences, 23(2): 4550.

Annawaty, A. and Wowor, D. (2015). The atyid shrimps from lake Lindu, Central Sulawesi, Indonesia with description of two new species (Crustacea: Decapoda: Caridea). Zootaxa, 3957(5): 501-519.

Ara, M.G.; Nobi, M.N. ; Fatema, M.K. and Ahmed, Z.F. (2014). Evaluation of condition factor of a small indigenous freshwater prawn, Macrobrachium lamarrei (H. MilneEdwards, 1837) in Bangladesh. Int. J. Nat. Soc. Sci., 1(12): 71-76.

Bauer, R. T. (2013). Amphidromy in shrimps: a life cycle between rivers and the sea. Lat Am J Aquat Res 41(4): 633-650.

Baye, T.M.; Abebe, T. and Wilke, R.A. (2011). Genotype-environment interactions and their 
translational implications. Per. Med. 8(1): 59-70.

Binur, R. and Pancoro, A.D.I. (2017). Inbreeding depression level of post-larvae freshwater prawn (Macrobrachium rosenbergii) from several hatcheries in Java, Indonesia. Biodiversitas, 18(1), 609-618.

Bister, T.J.; Willis, D.W. ; Brown, M.L. ; Jordan, S.M. ; Neumann, R.M. ; Quist, M.C. and Guy, C.S. (2000). Proposed standard weight (Ws) equations and standard length categories for 18 warmwater Nongame and riverine fish species. N. Am. J. Fish. Manag., 20(2): 570 574.

Blackwell, B.G.; Brown, M.L. and Willis, D.W. (2000). Relative weight (Wr) status and current use in fisheries assessment and management. Rev. Fish. Sci., 8(1): 1-44.

Cartaxana, A. (2015). Morphometric and molecular analyses for populations of Palaemon longirostris and Palaemon garciacidi (Crustacea, Palaemonidae): Evidence for a single species. Estuar. Coast. Shelf Sci., 154: 194-204.

Chace, F.A. J. and Bruce, A. J. (1993). The caridean shrimps (Crustacea: Decapoda) of the Albatross Philippine expedition 1907-1910, Part 6: Superfamily Palaemonoidea. In: "Smithsonian Contributions to Zoology", pp. 1-152.

Chang, Y.J.; Sun, C.L. ; Chen, Y. and Yeh, S.Z. (2012). Modelling the growth of crustacean species. Rev. Fish. Biol. Fisher., 22(1): 157-187.

Chen, P. C.; Tzeng, T.D. ; Shih, C.H. ; Chu, T.J. and Lee, Y.C. (2015). Morphometric variation of the oriental river prawn (Macrobrachium nipponense) in Taiwan. Limnologica, 52: 51-58.

Cuvin-Aralar, M.L.A. (2014). Embryonic development of the Caridean prawn Macrobrachium mammillodactylus (Crustacea: Decapoda: Palaemonidae). Invertebr. Reprod. Dev., 58(4): 306-313.

Datta, S.N.; Kaur, V.I. ; Dhawan, A. and Jassal, G. (2013). Estimation of length-weight relationship and condition factor of spotted snakehead Channa punctata (Bloch) under different feeding regimes. SpringerPlus, 2(436): 1-5.

de Grave, S.; Cai, Y. and Anker, A. (2008). Global diversity of shrimps (Crustacea : Decapoda : Caridea) in freshwater. Hydrobiologia, 595(1): 287-293.

de Grave, S.; Fransen, C. ; and Harles H.J.M. (2011). Carideorum catalogus: the recent species of the Dendrobranchiate, Stenopodidean, Procarididean and Caridean shrimps (Crustacea : Decapoda). Zool. Meded., 85: 195-588.

de Grave, S.; Wowor, D. ; Ayhong, S. and Shy, J. (2013). Macrobrachium mammillodactylus. IUCN Red List, e.T197860A.

de Robertis, A. and Williams, K. (2008). Weight-length relationships in fisheries studies: the standard allometric model should be applied with caution. Trans. Am. Fish. Soc., 137(3): 707-719.

Deekae, S. N. and Abowei, J.F.N. (2010). Macrobrachium Macrobrachion (Herklots, 1851) length-weight relationship and fulton's condition factor in Luubara creek, Ogoni Land, Niger Delta, Nigeria. J. Anim. Vet. Adv., 2(4): 155-162.

Dwiyanto, D.; Fahri, F. and Annawaty, A. (2017). First report of freshwater shrimp Macrobrachium scabriculum (Heller, 1862) from Batusuya, Donggala, Sulawesi, Indonesia. Nat. Sci. J. Sci. Technol., 6(3): 254-262.

Dwiyanto, D.; Farajallah, A. and Annawaty, A. (2020). Notes on the distribution of Caridina Sulawesi, an endemic freshwater shrimp from Sulawesi, Indonesia. BIO Web of Conf., 19: 00001.

Fadli, A.; Binur, R. and Kawulur, E.I.J.J. (2018). Morphology variation of Macrobrachium lar (Fabricius, 1798) occuring in rivers of Manokwari, West Papua, Indonesia. HAYATI J. Biosciences, 25(1): 6-10.

Fagnon, S. M.; Chikou, A. ; Youssao, I. and Laleye, P. (2013). Caractérisation morphologique des populations de Sarotherodon melanotheron (Pisces, Cichlidae) en eaux douces et 
saumâtres au Sud Bénin. Int. J. Biol. Chem. Sci., 7(2): 619-630.

Ferrito, V.; Mannino, M.C. ; Pappalardo, A.M. and Tigano, C. (2007). Morphological variation among populations of Aphanius fasciatus Nardo, 1827 (Teleostei, Cyprinodontidae) from the Mediterranean. J. Fish Biol., 70(1): 1-20.

Froese, R. (2006). Cube law, condition factor and weight-length relationships: history, metaanalysis and recommendations. J. Appl. Ichthyol., 22(4): 241-253.

Gerritsen, H. D. and Mcgrath, D. (2007). Significant differences in the length-weight relationships of neighbouring stocks can result in biased biomass estimates: Examples of haddock (Melanogrammus aeglefinus, L.) and whiting (Merlangius merlangus, L.). Fish. Res., 85(1-2): 106-111.

Ginting, G. V.; Efizon, D. and Windarti. (2018). Identification and relative growth of prawns from the Sibam river, Pekanbaru, Riau. JOM Faperika University of Riau, 5: 1-15.

Hamid, M. A.; Mansor, M. and Siti-Azizah, M.N. (2015). Length-weight relationship and condition factor of fish populations in Temengor reservoir: indication of environmental health. Sains Malays., 44(1): 61-66.

Hindell, J. S.; Jenkins, G.P. and Womersley, B. (2008). Habitat utilisation and movement of black bream Acanthopagrus butcheri (Sparidae) in an Australian estuary. Mar. Ecol. Prog. Ser., 366(August): 219-229.

Holthuis, L. B. (1950). The Decapoda of the Siboga Expedition. Part X. The Palaemonidae collected by the Siboga and Snellius expeditions, with remarks on other species. Part I: Subfamily Palaemoninae, Leiden, 682pp.

Hossain, M. Y.; Ohtomi, J. ; Jaman, A. ; Jasmine, S. and Vadas Jr, R.L. (2012). Life history traits of the Monsoon River prawn Macrobrachium malcolmsonii (Milne-Edwards, 1844) (Palaemonidae) in the Ganges (Padma) River, Northwestern Bangladesh. J. Freshw. Ecol., 27(1): 131-142.

Hurtado, L. A.; Carrera, E. ; Adite, A. and Winemiller, K.O. (2013). Genetic differentiation of a primitive teleost, the African bonytongue Heterotis niloticus, among river basins and within a floodplain river system in Benin, West Africa. J. Fish Biol., 83(3): 682-690.

Ighwela, K. A.; Ahmed, A.B and Abol-Munafi, A.B. (2011). Condition factor as an indicator of growth and feeding intensity of nile tilapia fingerlings (Oreochromis niloticus) feed on different levels of maltose. Am. Eurasian J. Agric. Environ. Sci., 11(4): 559-563.

Jayachandran, K. V. and Indira, B. (2010). Sustainable exploitation of freshwater prawn diversity of india for food and livelihood security with emphasis on planning. Indian J. Sci. Res., 1(2): 127-132.

Jisr, N.; Younes, G. ; Sukhn, C. and El-dakdouki, M.H. (2018). Length-weight relationships and relative condition factor of fish inhabiting the marine area of the Eastern Mediterranean city, Tripoli-Lebanon. $\quad$ Egypt. J. Aquat. Res., 44(4): 299-305.

Jose, D. and Harikrishnan, M. (2018). Evolutionary history of genus Macrobrachium inferred from mitochondrial markers: a molecular clock approach. Mitochondrial DNA A, 1-9.

Jurniati; Arfiati, D. ; Andriyono, S. ; Hertika, A.M.S. ; Kurniawan, A. and Tanod, W.A. (2021). The morphological characters and DNA barcoding identification of sweet river prawn Macrobrachium esculentum (Thallwitz, 1891) from Rongkong watershed of South Sulawesi, Indonesia. Biodiversitas, 22(1): 113-121.

Jurniati; Arfiati, D. ; Hertika, A.M.S. and Kurniawan, A. (2020). Length weight relationships and condition factor of sweet river prawn, Macrobrachium esculentum (Thalwitss, 1891) in the downstream Rongkong watershed. IOP Conf. Ser. Earth Environ. Sci. 441: 012093.

Kazemi, H.; Paighambari, S.Y. ; Daliri, M. and Naderi, R.A. (2013). Length-weight and length-length relationships, condition factors and optimal length of some fish species from the Persian Gulf and Oman Sea. Int. J. Aquat. Biol., 1(4): 167-174.

King, M. (2007). Fisheries biology, assessment and management (Second). Blackwell Publishing Ltd, London, 408pp. 
Konan, K. M.; Adépo-Gourène, A.B. ; Ouattara, A. ; Nyingy, W.D. and Gourène, G. (2010). Morphometric variation among male populations of freshwater shrimp Macrobrachium vollenhovenii Herklots, 1851 from Côte d'Ivoire Rivers. Fish. Res., 103(1-3): 1-8.

Konan, K. M.; Ouattara, A. ; Da Costa, K.S. ; Adépo-Gourène, A.B. and Gourène, G. (2014). Allometric growth and condition factor of West African shrimp, Macrobrachium vollenhovenii (Herklots, 1857), in the rivers of Co^te d'Ivoire. Mar. Freshwater Res., 65: 849-856.

Kounthongbang, A.; Lasasimma, O. ; Souliyamath, P. ; Iguchi, K. and Ito, S. (2015). Life history characteristics of the fluvial shrimp Macrobrachium yui (Holthuis, 1950) (Decapoda, Palaemonidae) spawning in the cave streams in northern Laos. Crustaceana, 88(2): 164-183.

Kumar, K.; Rana, A.R. and Kotnala, C.B. (2018). Taxonomic study and identification character of freshwater prawn Macrobrachium assamense peninsulare (Tiwari, 1958) in Garhwal region of Central Himalaya, India. Int. J. Res. Anal. Rev., 5(4): 485-491.

Laewa, N. H.; Fahri, F. and Annawaty, A. (2018). The freshwater prawn Macrobrachium latidactylus (Decapoda, Caridea, Palaemonidae) from Gililana river, North Morowali, Sulawesi, Indonesia. Nat. Sci. J. Sci. Technol., 7(2): 205-216.

Lawson, E. O. (2010). Morphometric measurements and meristic counts in mudskipper (Periophthalmus papilio) from mangrove swamps of Lagos lagoon, Nigeria. J. Appl. Biosci., 34: 2166-2172.

Le Cren, E. D. (1951). The length-weight relationship and seasonal cycle in gonad weight and condition in the Perch (Perca fluviatilis). J. Anim. Ecol., 20(2): 201-219.

Llopis-belenguer, C.; Blasco-costa, I. and Balbuena, J.A. (2018). Evaluation of three methods for biomass estimation in small invertebrates, using three large disparate parasite species as model organisms. Sci. Rep., 8(3897): 1-9.

Maidin, M. S. R.; Anton, A. ; Yong, A.S.K. and Chin, G.J.W.L. (2017). Mitochondrial COI gene Sequence of giant freshwater prawn, Macrobrachium rosenbergii: An assessment of a community-based stock enhancement programme in Petagas river, Sabah, Malaysia. Int. J. Fish. Aquat. Stud., 5(2): 518-526.

Mangesa, H. E.; Fahri, F. and Annawaty, A. (2016). Inventory of the freshwater shrimp in Toranda stream, Palolo, Sigi, Central Sulawesi, Indonesia. Nat. Sci. J. Sci. Technol., 5(3): 288-295.

Mar, W.; Kang, E.F. ; Mao, B. and Wang, Y.F. (2018). Morphological and molecular features of some freshwater prawn species under genus Macrobrachium spence Bate, 1868 (Crustacea: Decapoda: Palaemonidae) from Myanmar. Zootaxa, 4388(1): 123-132.

Mariappan, P. and Balasundaram, C. (2004). Studies on the morphometry of Macrobrachium nobilii (Decapoda, Palaemonidae). Braz. Arch. Biol. Techno., 47(3): 441-449.

Maurya, A. K.; Animal, K. ; Sahu, P. ; Prasad, L. ; Pal, J. and Shukla, B. (2018). Length weight relationship and condition factor of Mystus bleekeri (Day, 1877) in Rudrasagar lake, a Ramsar site in Tripura. J. Entomol. Zool. Stud., 6(2): 2500-2503.

Menajang, F. S. I.; Herawati, E.Y. ; Mahmudi, M. ; Yanuhar, U. and Tanod, W.A. (2020). Distribution of seagrass in the coast of Bahoi, Manembo-nembo and Tandurusa, North Sulawesi, Indonesia. Russ. J. Agric. Socio- Econ. Sci., 2(98): 3-11.

Mossolin, E. C.; Pileggi, L.G. and Mantelatto, F.L. (2010). Crustacea, Decapoda, Palaemonidae, Macrobrachium Bate, 1868, São Sebastião Island, state of São Paulo, southeastern Brazil. Check List, 6(4): 605-613.

Moutopoulos, D. K. and Stergiou, K.I. (2002). Length-weight and length-length relationships of fish species from the Aegean sea (Greece). J. Appl. Ichthyol., 18(3): 200-203.

Muchlisin, Z. A.; Musman, M. and Siti-Azizah, M.N. (2010). Length-weight relationships and condition factors of two threatened fishes, Rasbora tawarensis and Poropuntius tawarensis, endemic to Lake Laut Tawar, Aceh Province, Indonesia. J. Appl. Ichthyol., 26(6): 949-953.

Munasinghe, D. and Thushari, G. (2010). Analysis of morphological variation of four 
populations of Macrobrachium rosenbergii (de man, 1879) (Crustacea: Decapoda) in Sri Lanka. Ceylon J. Sci. Biol. Sci., 39(1): 53-60.

Murphy, B. R.; Willis, D.W. and Springer, T.A. (1991). The relative weight index in fisheries management: status and needs. Fisheries, 16(2): 30-38.

Ndiaye, W.; Diouf, K. ; Samba, O. ; Ndiaye, P. and Panfili, J. (2015). The length-weight relationship and condition factor of white grouper (Epinephelus aeneus, Geoffroy Saint Hilaire, 1817) at the South-West coast of Senegal, West Africa. Int. J. Adv. Res., 3(3): 145153.

Neumann, R. M.; Guy, C.S. and Willis, D.W. (2012). Length, Weight, and Associated Structural Indices. In: "Fisheries Techniques." Zale, A.V.; Parrish, D.L. \& Sutton, T. M. (Eds.). American Fisheries Society, Maryland, pp. 451-478.

Nurmanita, T.; Windarti, and Efawani. (2019). Prawns identification in the Pangkal Tanjung Balam lake, Siak Hulu Sub-Regency, Kampar. Thesis. Faculty of Fisheries and Marine, Riau University. Riau, Indonesia, 67pp.

Offem, B. O.; Akegbejo-samsons, Y. ; and Omoniyi, I.T. (2007). Biological assessment of Oreochromis niloticus (Pisces: Cichlidae; Linne, 1958) in a tropical floodplain river. Afr. J. Biotechnol., 6(16): 1966-1971.

Ogunola, O. S.; Onada, O.A. and Falaye, A.E. (2018). Preliminary evaluation of some aspects of the ecology (growth pattern, condition factor and reproductive biology) of African pike, Hepsetus odoe (Bloch 1794), in Lake Eleiyele, Ibadan, Nigeria. Fish. Aquat. Sci., 21(12): 115.

Okgerman, H. (2005). Seasonal variations in the length-weight relationship and condition factor of Rudd (Scardinius erythrophthalmus L.) in Sapanca lake. Int. J. Zool. Res., 1(1): 6-10.

Oliveira, M. S. B.; Silva, L.M.A.; Prestes, L. and Tavares-dias, M. (2020). Length-weight relationship and condition factor for twelve fish species from the Igarapé Fortaleza basin, a small tributary of the Amazonas River estuary. Acta Amaz., 50(1): 8-11.

Peixoto, S.; Soares, R. ; Wasielesky, W. ; Cavalli, R.O. and Jensen, L. (2004). Morphometric relationship of weight and length of cultured Farfantepenaeus paulensis during nursery, grow out, and broodstock production phases. Aquaculture, 241(1-4): 291-299.

Rahayu, P. and Annawaty, A. (2019). Composition of freshwater shrimps in Batambean stream, Labobo island, Banggai Laut, Central Sulawesi, Indonesia. Nat. Sci. J. Sci. Technol., 8(2): $120-126$.

Richter, T. J. (2007). Development and evaluation of standard weight equations for bridgelip suckers and largescale suckers. N. Am. J. Fish. Manag., 27(3): 936-939.

Ricker, W. E. (1973). Linear regressions in fishery research. J Fish Res Board Can., 30(3): 409434.

Rypel, A. L. and Richter, T. J. (2008). Empirical percentile standard weight equation for the blacktail redhorse. N. Am. J. Fish. Manag., 28(6): 1843-1846.

Setiawan, O. and Nandini, R. (2006). Study of biophisic and social economy of community for supporting Rongkong watershed management. J. Forest Res. Nat. Conserv., III(4): 401-419.

Short, J. W. (2004). A revision of Australian river prawns, Macrobrachium (Crustacea: Decapoda: Palaemonidae). Hydrobiologia, 525(1-3): 1-100.

Silva, T. S. de C.; dos Santos, L.D. ; da Silva, L.C.R. ; Michelato, M.; Furuya, V. R.B. and Furuya, W.M. (2015). Length-weight relationship and prediction equations of body composition for growing-finishing cage-farmed Nile tilapia. Rev. Bras. Zootecn., 44(4): 133-137.

Smith, M. T. and Addison, J.T. (2003). Methods for stock assessment of crustacean fisheries. Fish. Res., 65(1-3): 231-256.

Stevenson, R. D. and Woods, W.A. (2006). Condition indices for conservation: new uses for evolving tools. Integr. Comp. Biol., 46(6): 1169-1190. 
Swiyanto, D.; Fahri, F. and Annawaty, A. (2018). Freshwater shrimp diversity (Decapoda: Caridea) in the Batusuya river, Central Sulawesi, Indonesia. Scr. Biol., 5(2): 65-71.

Tanod, W. A.; Dewanto, D.K. ; Ndobe, S. ; Riyadi, P.H. and Putra, M.Y. (2019). Screening of antibacterial and antioxidant activity from the soft corals Sinularia sp. and Sarcophyton sp. origin Palu bay, Central Sulawesi, Indonesia. Squalen Bull. Mar. Fish. Postharvest Biotechnol., 14(2): 73-83.

Tizkar, B.; Seidavi, A. and Ponce, J. (2018). Study of some morphometric, meristic characters and length-weight relationship in wild and domestic populations of the eastern river prawn, Macrobrachium nipponense (De Haan, 1849) (Crustacea: Decapoda: Palaemonidae), in Iranian Basin of the Caspian Sea. Iran. J. Fish. Sci., 19(4): 2173-2184.

Torati, L. S.; de Grave, S. ; Page, T.J. and Anker, A. (2011). Atyidae and palaemonidae (Crustacea: Decapoda: Caridea) of Bocas del Toro, Panama. Check List, 7(6): 798-805.

Trijoko; Handayani, N.S.N. ; Widianawati, A. and Eprilurahman, R. (2015). Morphological and Molecular Characters of Macrobrachium spp. Biogenesis Jurnal Ilmiah Biologi, 3(1): $1-10$.

Wahidah; Omar, S.B.A ; Trijuno, D.D. ; Nugroho, E. and Amrullah. (2017). The morphological characteristics of south Sulawesi's giant freshwater prawn Macrobrachium rosenbergii. AACL Bioflux, 10(4): 820-829.

Wahidah; Omar, S.B.A. ; Trijuno, D.D. and Nugroho, E. (2015). Morphometric variance of South Sulawesi's freshwater prawn Macrobrachium rosenbergii and Macrobrachium idae. Int. J. Sci. Res. Pub., 5(4): 1-5.

Wowor, D. and Choy, S. C. (2001). The freshwater prawns of the genus Macrobrachium Bate, 1868 (Crustacea: Decapoda: Palaemonidae) from Brunei Darussalam. Raffles B. Zool., 49(2): 269-289.

Wowor, D.; Muthu, V. ; Meier, R. ; Balke, M. ; Cai, Y. and Ng, P.K.L. (2009). Molecular phylogenetics and evolution of life history traits in Asian freshwater prawns of the genus Macrobrachium (Crustacea: Decapoda: Palaemonidae) based on multilocus molecular phylogenetic analysis. Mol. Phylogenet. Evol., 52(2): 340-350. 